Prepared in cooperation with the Clackamas River Water Providers and

Clackamas County Water Environment Services

\title{
Seepage Investigations of the Clackamas River, Oregon
}

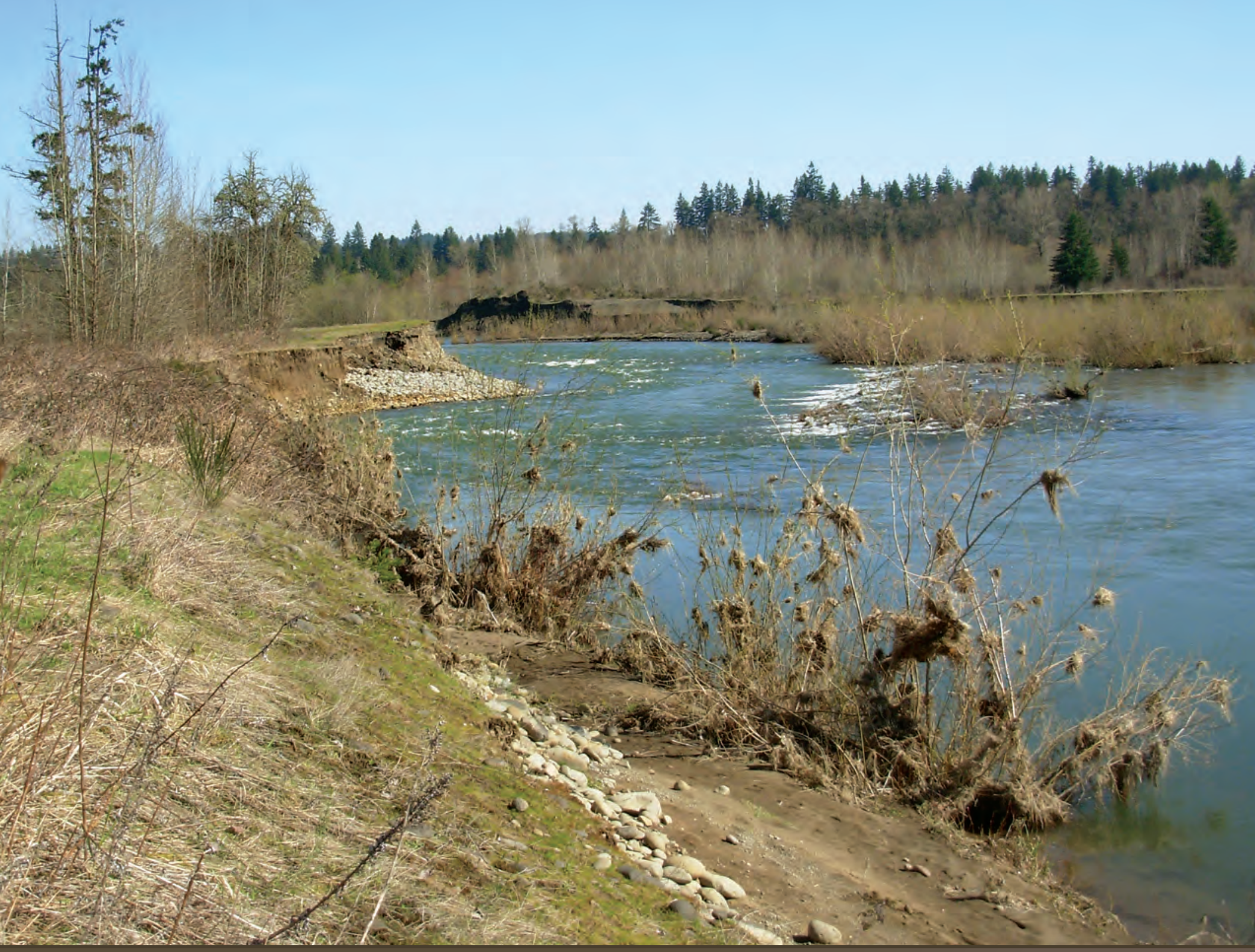

Scientific Investigations Report 2011-5191

U.S. Department of the Interior

U.S. Geological Survey 
Cover: Clackamas River near Barton, Oregon. (Photograph by Karl Lee, April 4, 2009). 


\section{Seepage Investigations of the Clackamas River, Oregon}

By Karl K. Lee

Prepared in cooperation with the Clackamas River Water Providers and Clackamas County Water Environment Services

Scientific Investigations Report 2011-5191 


\title{
U.S. Department of the Interior \\ KEN SALAZAR, Secretary \\ U.S. Geological Survey \\ Marcia K. McNutt, Director
}

\author{
U.S. Geological Survey, Reston, Virginia: 2011
}

For more information on the USGS - the Federal source for science about the Earth, its natural and living resources, natural hazards, and the environment, visit http://www.usgs.gov or call 1-888-ASK-USGS.

For an overview of USGS information products, including maps, imagery, and publications, visit http://www.usgs.gov/pubprod

To order this and other USGS information products, visit http://store.usgs.gov

Any use of trade, product, or firm names is for descriptive purposes only and does not imply endorsement by the U.S. Government.

Although this report is in the public domain, permission must be secured from the individual copyright owners to reproduce any copyrighted materials contained within this report.

Suggested citation:

Lee, K.K., 2011, Seepage investigations of the Clackamas River, Oregon: U.S. Geological Survey Scientific Investigations Report 2011-5191, 16 p. 


\section{Contents}

Abstract
Introduction.
Purpose and Scope
Study Area.
Rethods
Results of Seepage Analyses
Results from Analysis of Previous Studies from Analysis of Long-Term Streamflow Data
Suggestions for Further Study
Acknowledgments
References Cited.

\section{Figures}

Figure 1. Map showing location and features of the Clackamas River basin, Oregon, and streamflow measurement sites in the upper basin..

Figure 2. Map showing streamflow measurement and withdrawal sites and reaches with streamflow gains or losses in the lower Clackamas River, Oregon,

September 2006.

Figure 3. Graph showing streamflow in the Clackamas River, Oregon, September 5-8, 2006, and the time spans of manual streamflow measurement for the synoptic seepage study

Figure 4. Graph showing monthly mean streamflow of the Clackamas River at Estacada, Oregon (site 5)

Figure 5. Graph showing streamflow gains and losses of the lower Clackamas River, Oregon, based on measurements during August-September 1963-83 and 2001-06 .....10

Figure 6. Graph showing streamflow gains and losses of the lower Clackamas River, Oregon, September 2006

\section{Tables}

Table 1. Streamflow measurement and withdrawal sites used in the estimation of streamflow gains and losses in the Clackamas River basin, Oregon...

Table 2. Streamflow gains and losses in the lower Clackamas River, Oregon, 1963-2006 ............8

Table 3. Streamflow gains of the Clackamas River, Oregon, within three hydrogeologic areas of the Willamette River basin, 1963-83 and 2001-06

Table 4. Streamflow gains and losses in the lower Clackamas River, Oregon, September 6-7, 2006 


\section{Conversion Factors and Datums}

Conversion Factors

\begin{tabular}{|c|c|c|}
\hline Multiply & By & To obtain \\
\hline foot $(\mathrm{ft})$ & 0.3048 & meter $(\mathrm{m})$ \\
\hline mile (mi) & 1.609 & kilometer (km) \\
\hline square mile $\left(\mathrm{mi}^{2}\right)$ & 2.590 & square kilometer $\left(\mathrm{km}^{2}\right)$ \\
\hline cubic foot $\left(\mathrm{ft}^{3}\right)$ & 0.02832 & cubic meter $\left(\mathrm{m}^{3}\right)$ \\
\hline cubic foot per second $\left(\mathrm{ft}^{3} / \mathrm{s}\right)$ & 0.02832 & cubic meter per second (m³/s) \\
\hline $\begin{array}{l}\text { cubic foot per second per square } \\
\text { mile }\left(\mathrm{ft}^{3} / \mathrm{s}\right) / \mathrm{mi}^{2}\end{array}$ & 0.01093 & $\begin{array}{l}\text { cubic meter per second per square } \\
\text { kilometer }\left(\mathrm{m}^{3} / \mathrm{s}\right) / \mathrm{km}^{2}\end{array}$ \\
\hline
\end{tabular}

Datums

Vertical coordinate information is referenced to the North American Vertical Datum of 1988 (NAVD 88).

Horizontal coordinate information is referenced to the North American Datum of 1983 (NAD 83).

Elevation, as used in this report, refers to distance above the vertical datum. 


\title{
Seepage Investigations of the Clackamas River, Oregon
}

\author{
By Karl K. Lee
}

\section{Abstract}

Analysis of streamflow measurements and continuous records of streamflow provided insight into interaction of the groundwater system with the Clackamas River in northwestern Oregon. This report assesses gains and losses of the Clackamas River based on streamflow measurements made during previous hydrologic studies, decades of continuous streamflow data, and a detailed suite of streamflow measurements made in September 2006. Gains and losses were considered significant if, after accounting for tributary inflows and withdrawals, the difference in streamflow from a measurement site to the next site downstream exceeded the streamflow measurement uncertainty. Streamflow measurements made in 1987, 1992, and 1998 indicated minor gains and losses. Comparison of continuous records of late summer streamflow of the Clackamas River at Estacada to sites at Clackamas and Oregon City indicated gains in some years, and no losses. Analysis of streamflow measurements of the Clackamas River from Estacada to Oregon City during low-flow conditions in September 2006 enabled an estimation of gains and losses on a reach-by-reach scale; these gains and losses were attributable to the geomorphic setting. During late summer, most groundwater discharge occurs upstream of Estacada, and groundwater contributions to streamflow downstream of Estacada are minor.

\section{Introduction}

The Clackamas River (fig. 1) provides drinking water for about 300,000 people and supports native fish populations as well as numerous other species (Clackamas River Water Providers, 2011). The Clackamas River currently provides downstream communities with a reliable source of municipal and drinking water while meeting in-stream requirements for fish. However, demand for water for municipal, irrigation, recreational, and in-stream uses in the basin is increasing.

The sources of water for streams that drain the western slopes of the Cascade Range in northwestern Oregon, including the Clackamas River, are snowmelt and rain that reach the streams by way of surface runoff or discharge from the groundwater system after percolating through soils and fractured rock (Piper, 1942; Lee and Risley, 2002). Characteristics of the connections between the groundwater and surface-water systems in the Clackamas River basin have not been well defined, and to evaluate the quantity and quality of water available to water providers, an improved understanding of those connections is necessary. The study described herein was an assessment of streamflow gains and losses in the Clackamas River, which are a result of groundwater contributions to the river (gains) and groundwater recharge from the river (losses). The study was a cooperative effort of the U.S. Geological Survey (USGS) and the Clackamas Watershed Management Group (Clackamas River Water Providers and Clackamas County Water Environment Services).

\section{Purpose and Scope}

The purpose of this report is to present an assessment of the interaction of the stream and groundwater system of the Clackamas River basin by analysis of gains and losses in streamflow. Data available for this analysis consists of streamflow measurements made during previous hydrologic investigations on the Clackamas River in 1987, 1992, 1998, and 2001; continuous records of streamflow from 1963 through 1983 and 2001 through 2006; and a detailed suite of streamflow measurements made during baseflow conditions in 2006.

\section{Study Area}

The primary focus area of this study is the lower Clackamas River from Estacada to its confluence with the Willamette River in Oregon City. This segment of the river is about $20 \mathrm{mi}$ long and flows from east to west, from an elevation of about $300 \mathrm{ft}$ at Estacada to near sea level at the confluence with the Willamette River in Oregon City (fig. 1) (Carpenter, 2003). Stream width at low flows range from about 200 to $300 \mathrm{ft}$. The river flows primarily in a single channel, although the stream channel is braided in places. From Estacada to Carver, the stream flows over quaternary alluvium (Madin, 1994). The stream narrows at Carver in a gap between hills and flows over Pleistocene volcanic sandstone overlain by thin alluvial deposits. Downstream of Carver the stream again intersects alluvial deposits and is bounded on the south by Troutdale Formation gravels and on the north by Pleistocene Clackamas River terrace deposits (Madin, 1990). 


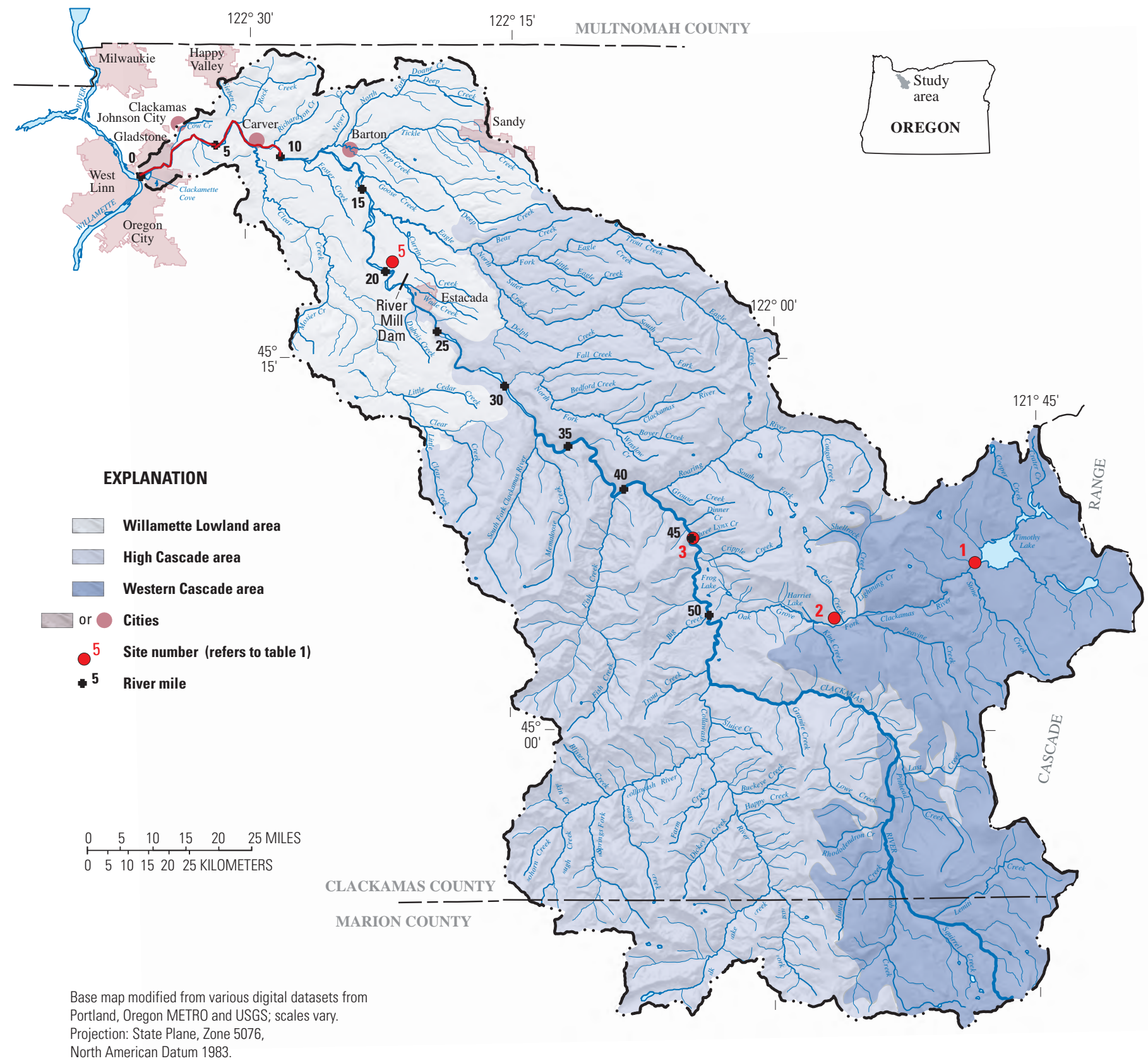

Figure 1. Location and features of the Clackamas River basin, Oregon, and streamflow measurement sites in the upper basin. 
Land use follows a gradient, from primarily forest near Estacada to a mix of agricultural and rural residential land uses toward the west. Land use adjacent to the stream in the lowest several miles of the Clackamas River is urban and industrial. The towns of Estacada, Carver, Clackamas, and Oregon City are situated along the river. This report also includes discussion of streamflow in the upper Clackamas River from Timothy Lake to Estacada by way of the Oak Grove Fork of the Clackamas River, a distance of about 42 river miles.

Precipitation in the basin falls as rain and snow. The headwater area of the Clackamas River, at an elevation of about $7,000 \mathrm{ft}$, accumulates snow each year, but by late summer, the basin is generally snow free. The period of primary interest for this study is the summer base-flow period, when precipitation is minimal and streamflow is sustained primarily by groundwater discharge. For the combined months of August and September, the average precipitation at Estacada during 1971-2000 was 3.4 in., about 6 percent of the annual total (PRISM Group, 2008).

Streamflow of the Clackamas River is regulated by several reservoirs. During the summer low-flow season, streamflow in the lower river is regulated by River Mill Dam, a hydroelectric facility at Estacada (fig. 1). Long-duration fluctuations during summer are due to water releases at Timothy Lake, a storage reservoir in the upper Clackamas River basin.

\section{Methods}

Analyses discussed in this report consist of an accounting procedure in which a gain or loss in streamflow, termed seepage, from one measurement site to the next site downstream is attributed to interaction with the groundwater system after compensating for known withdrawals and tributary inflows. A gain in streamflow indicates that groundwater is flowing into the stream through the streambed or by way of bankside seepage, whereas a loss indicates that stream water is flowing into the groundwater system through the streambed. Values of net anthropogenic withdrawals between two measurement sites are added to the measured streamflow at the downstream site, whereas intervening tributary inflow is subtracted from the measured streamflow at the downstream site. The result is the net gain or loss in streamflow from the upstream measurement site to the downstream measurement site. Values for tributary inflows were available during only some of the studies and, therefore, were sometimes estimated based on streamflow measurements made in tributaries during the same season in other years. Analyses are from the base-flow period, typically August-September, when streamflow is minimally affected by surface runoff from precipitation.

The basic components of this seepage investigation were individual streamflow measurements and continuous records of streamflow. All data are available online at http://waterdata. usgs.gov/or/nwis/sw using the 8- or 15-digit USGS site number, as appropriate.
Streamflow measurements made at numerous locations during a short (1-2 day) period enable the reconstruction of a synoptic "snapshot" of seepage. Streamflow measurement sites (the location of the actual measurement) and streamflow monitoring sites (the source of continuous streamflow records) are identified by site in table 1 and shown in figure 2 . Measurement sites on the lower Clackamas River were associated with the river mile, measured from 2005 aerial photography (Oregon State University, 2008), and may differ in their river mile location from previously published reports and maps, primarily due to channel changes that resulted from a major flood in 1996. Streamflow was measured using mechanical or acoustical meters, following guidelines of Rantz and others (1982) and Oberg and others (2005), respectively.

Seepage also can be interpreted on a monthly to seasonal time scale on the basis of streamflow records from USGS monitoring sites for the low-flow period each year. Continuous streamflow records are obtained by applying a "stage-discharge" rating to automatically recorded stream levels (stage) to obtain a series of estimated streamflow (discharge) values. The stage-discharge rating for a monitoring site is developed from the relation of stream levels to manually measured streamflows associated with those stream levels (Rantz and others, 1982). Determining gains and losses from long-term streamflow record has advantages and disadvantages compared to the synoptic approach. The primary advantage is that the effect of hour-by-hour streamflow fluctuations on the data record is muted. This method is also cost-effective because it uses existing daily streamflow data collected for multiple purposes and does not require coordination of a team of hydrographers to measure streamflow at a given time. The primary disadvantage is that the long-term record includes unmeasured streamflow contributions from tributaries; as a result, main-stem streamflow cannot be mathematically isolated. Additionally, surface-runoff events sometimes occur during late summer. Depending on runoff characteristics of the basin upstream of Estacada relative to downstream, differences in streamflow might be incorrectly interpreted as gains or losses due to seepage. However, the effect of surface runoff is probably minimal due to infrequent summer precipitation and seasonally high evaporative losses.

The overall accuracy of a seepage investigation depends on the accuracy of the determination of streamflow difference from one measurement site to the next. The difference in streamflow, whether calculated from discrete streamflow measurements or continuous streamflow records, must be equal to or greater than the uncertainty of that difference to be considered significant. The estimation of streamflow uncertainty is based on ambient conditions and the methods used to measure the components of streamflow: stream velocity, channel depth, and channel width (Rantz and others, 1982). For this study, the range of uncertainty was 5-11 percent, depending on measurement method and stream channel characteristics. 
Table 1. Streamflow measurement and withdrawal sites used in the estimation of streamflow gains and losses in the Clackamas River basin, Oregon.

[Locations of sites are shown in figures 1 and 2. Abbreviations: (a) tributary enters or withdrawal from Clackamas River at specified river mile; USGS, U.S. Geological Survey; -, not applicable]

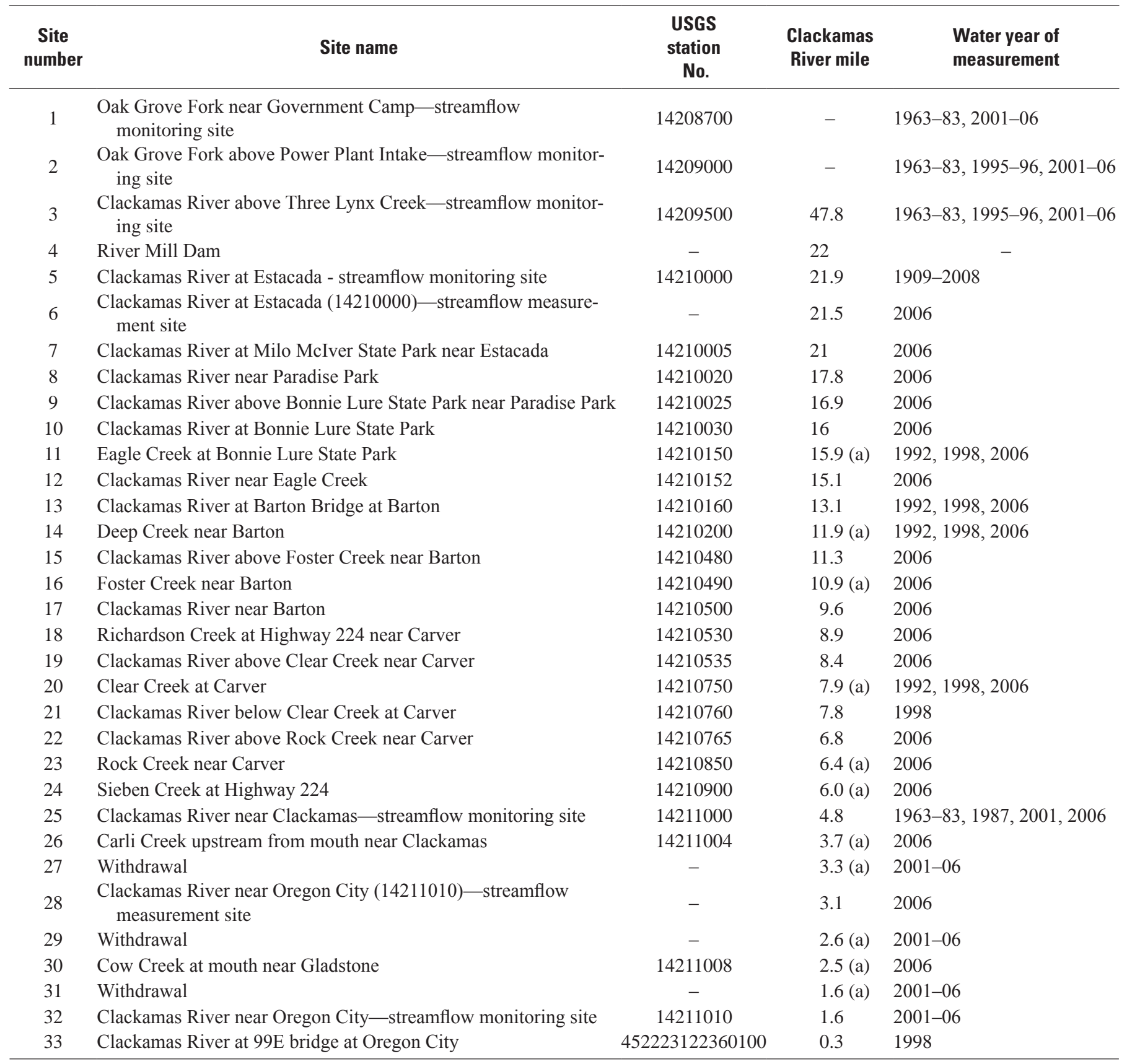




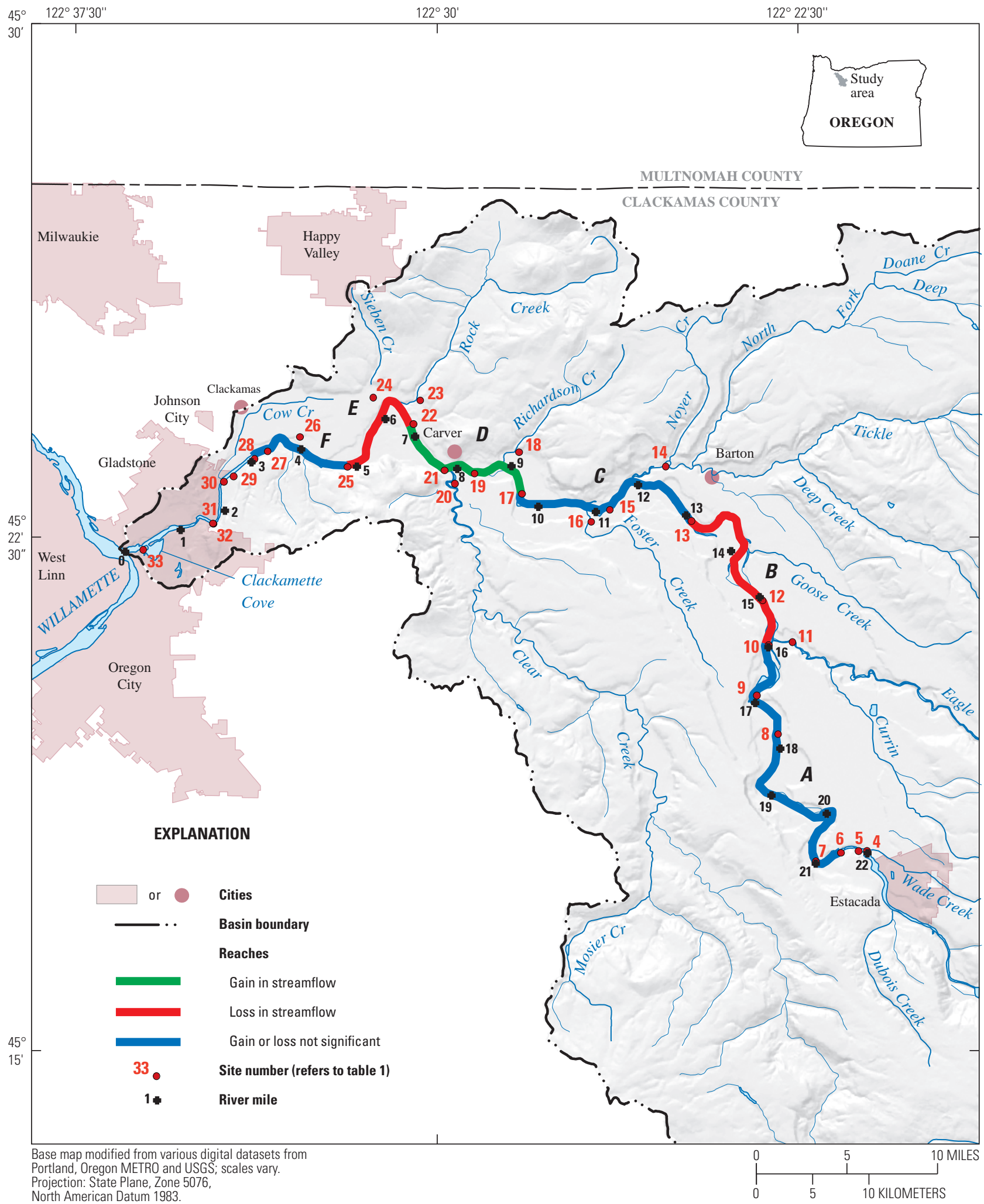

Figure 2. Streamflow measurement and withdrawal sites and reaches with streamflow gains or losses in the lower Clackamas River, Oregon, September 2006. 
Continuous streamflow records have inherent uncertainty that is determined by the accuracy of the stage record and the reliability of the stage-discharge relation, which is determined in large part by the frequency of manual streamflow measurements to verify the relation over time and environmental factors, such as the stability of the stream channel. Continuous streamflow records are rated annually, and for Clackamas River monitoring sites used in this study ranged from "excellent" to "poor" on an annual basis, depending on the site, representing an uncertainty of 5 percent to greater than 15 percent of the true value. In this seepage study, however, low flows were of primary interest. Low flows generally can be estimated more accurately than flows during other times of the year because the streambed is likely more stable than during the high-flow season. Consequently, continuous streamflow records were assigned an uncertainty of 10 percent of the true value.

Another source of uncertainty in a seepage investigation is the possibility of a rapid change in streamflow (pulse) in response to release changes from a reservoir. River Mill Dam (site 4, fig. 2, table 1) on the Clackamas River is the primary source of pulses in the reaches discussed in this report. Whereas a pulse is easily identified at the streamflow site immediately downstream of the dam (site 5) by an almost instantaneous change in streamflow, the translation of a pulse, in timing and magnitude, to the downstream sites is less certain. The travel time of flow pulses was estimated on the basis of continuous streamflow at Estacada (site 5) and Oregon City (site 32) (fig. 3). The time delay between a pulse in streamflow at the upstream site and its arrival at the downstream site was 5-8 hours for the range of streamflow discussed in this report. These results were used in a qualitative sense for the analysis of gains and losses of the Clackamas River and, particularly, to exclude comparisons of streamflow during times of increased (or decreased) streamflow due to changes in reservoir releases.

Finally, reported withdrawals are also subject to uncertainty. For this study, withdrawals were relatively small compared to streamflow of the Clackamas River, and the reported values were incorporated into the seepage accounting using an estimated uncertainty of 5 percent.

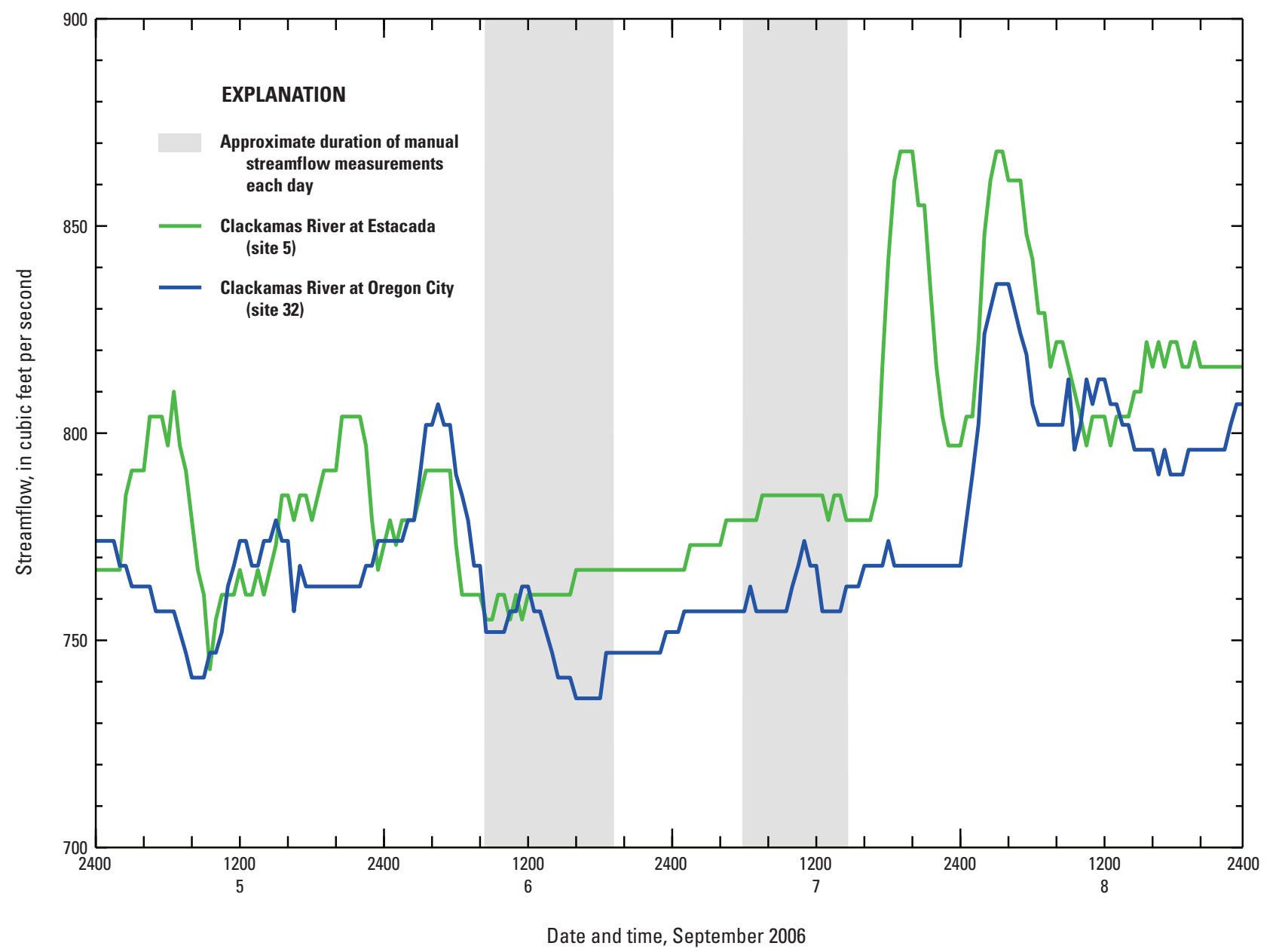

Figure 3. Streamflow in the Clackamas River, Oregon, September 5-8, 2006, and the time spans of manual streamflow measurement for the synoptic seepage study. 


\section{Results of Seepage Analyses}

Seepage characteristics of the Clackamas River were determined by using a combination of three methods: (1) analysis of previous studies that made synoptic measurements, (2) comparisons of daily means of long-term, continuous streamflow records, (3) a synoptic seepage study in 2006.

\section{Results from Analysis of Previous Studies}

Previous studies, with various primary purposes, made synoptic streamflow measurements of the Clackamas River and tributaries. Although some of these studies provided insight into seepage characteristics, on the basis of streamflow measurements and continuous streamflow records collected during base-flow or near-base-flow conditions, some were not suitable for this analysis owing to fluctuating streamflow and/or lack of tributary measurements.

Streamflow was measured at the Clackamas River near Clackamas site (site 25) as part of a statewide inventory during the droughts of 1987 and 2001, and was compared to streamflow records at Estacada (site 5, table 2) (Alexander and others, 1987; Herrett and others, 2001). Intervening tributaries (Eagle, Deep, Clear, and Rock Creeks [sites 11, 14, 20, and 23 , respectively] were not measured). For the current analysis, tributary flow of $42 \mathrm{ft}^{3} / \mathrm{s}$ measured in late summer 2006 was assumed to be equivalent to late summer flow in 1987. In August 1987, the river gained $104 \mathrm{ft}^{3} / \mathrm{s}$ (16 percent), which was greater than the uncertainty. In September 2001, large pulses precluded comparison of flows.

Streamflow measurements of the Clackamas River were made as part of a time-of-travel study in 1992 (Lee, 1995). Streamflow measurements at Barton Bridge (site 13) and Eagle Creek (site 11) in May 1992, compared to streamflow at Estacada (site 5), indicated a loss of $150 \mathrm{ft}^{3} / \mathrm{s}$ (11 percent), greater than the uncertainty (table 2). Streamflow at the Barton site was measured in July 1992, but a pulse from River Mill Dam affected the flow.

Streamflow measurements of the Clackamas River and tributaries were made in May, July, and September 1998 associated with a water-quality study (Carpenter, 2003). The measurements covered a broad area, extending from upstream of Estacada to the mouth of the river. Unmeasured tributaries precluded use of the May measurements. Knowledge of the travel time of pulses at similar streamflow magnitude, derived from recent streamflow data from the Estacada site (5) and Oregon City site (32), suggests that the July 1998 measurements may have been made during unsteady conditions.
Streamflow measurements made at Barton Bridge (site 13), Carver (site 21), and Oregon City (site 33) in September 1998 were compared to recorded streamflow at Estacada. Tributary streamflows were not measured but were estimated to be equivalent to the late summer streamflows of September 2006. The difference in streamflow from Estacada to Barton Bridge was less than the uncertainty. The gain in streamflow between Barton Bridge and Carver of $200 \mathrm{ft}^{3} / \mathrm{s}$ (19 percent) was greater than the uncertainty. Although the Clackamas River was measured at Oregon City (site 33), this measurement was invalidated by fluctuating backwater conditions from the Willamette River.

In summary, analysis of streamflow measurements made during previous studies indicated some gains or losses that exceeded the uncertainty. The August 1987 measurements indicated a gain of 16 percent from Estacada to Clackamas. The May 1992 measurements indicated a loss of 11 percent from Estacada to Barton Bridge. The September 1998 measurements indicated a 19 percent gain from Barton Bridge to Carver and, on a larger scale, a gain of 25 percent for the reach from Estacada to Carver.

\section{Results from Analysis of Long-Term Streamflow Data}

Long-term streamflow data consisting of records of daily streamflow at several sites in the Clackamas River basin enabled the estimation of seepage to the stream.

Seepage in the lower Clackamas River during the annual base-flow period was determined by comparing streamflow at the Estacada site (site 5) to streamflow at sites downstream. The downstream sites are Clackamas River at Clackamas (site 25), from 1963 through 1983, and Clackamas River near Oregon City (site 32) from 2001 through 2006. After accounting for tributary inflows and municipal withdrawals, seepage was inferred from the difference between annual low streamflow at the Estacada site and the site downstream. Streamflow in the Clackamas River is lowest in late summer, and late summer streamflow is similar to what it was before construction of the dam on the Oak Grove Fork at Timothy Lake in 1958 (fig. 4). The August-September average streamflow (the average of all daily mean values during the comparison periods) is about $1,000 \mathrm{ft}^{3} / \mathrm{s}$. Whereas synoptic measurements describe gains and losses on a single day on a mile-by-mile basis, this analysis provides seepage estimates for each year of concurrent streamflow data between the sites, about $20 \mathrm{mi}$ apart. 
Table 2. Streamflow gains and losses in the lower Clackamas River, Oregon, 1963-2006.

[Site number: See table 1. Locations of reaches and sites are shown in figure 2. Values greater than streamflow uncertainty are depicted in bold. Downstream site streamflows are adjusted for tributary or withdrawal. Noted gains and losses are from upstream to downstream sites. A bbreviations: $\mathrm{ft}^{3} / \mathrm{s}$, cubic foot per second; +, gain from upstream site; -, loss from upstream site; (a), value from streamflow monitoring site; WY, water year (the year extending from October 1 of the previous year to September 30 of the year indicated]

\begin{tabular}{|c|c|c|c|c|c|c|c|c|}
\hline \multirow[b]{2}{*}{ Date } & \multicolumn{2}{|c|}{ Upstream site } & \multicolumn{2}{|c|}{ Downstream site } & \multirow{2}{*}{$\begin{array}{l}\text { Streamflow } \\
\text { uncertainty } \\
\text { (percent) }\end{array}$} & \multicolumn{2}{|c|}{ Gain or loss } & \multirow[b]{2}{*}{ Remarks } \\
\hline & $\begin{array}{c}\text { Site } \\
\text { number }\end{array}$ & $\begin{array}{l}\text { Streamflow } \\
\left(\mathrm{ft}^{3} / \mathrm{s}\right)\end{array}$ & $\begin{array}{c}\text { Site } \\
\text { number }\end{array}$ & $\begin{array}{c}\text { Streamflow } \\
\left(\mathrm{ft}^{3} / \mathrm{s}\right)\end{array}$ & & \multicolumn{2}{|c|}{$\left(\mathrm{ft}^{3} / \mathrm{s}\right)$ (percent) } & \\
\hline $08-26-1987$ & 5 & 650 (a) & 25 & 754 & 10 & +104 & +16 & $\begin{array}{l}\text { Estimated tributary inflow (site numbers } 11 \text {, } \\
\text { 14, 20, and 23) equal to September } 2006 \\
\text { measurements. }\end{array}$ \\
\hline 09-01-1998 & 5 & $1,000(a)$ & 13 & 1,060 & 10 & +60 & +6 & $\begin{array}{l}\text { Estimated tributary inflow (site number 11) } \\
\text { equal to September } 2006 \text { measurement. }\end{array}$ \\
\hline 09-01-1998 & 13 & 1,080 & 21 & 1,280 & 8 & +200 & +19 & $\begin{array}{l}\text { Estimated tributary inflow (site numbers 14, } \\
\text { 20) equal to September } 2006 \text { measurements. }\end{array}$ \\
\hline \multicolumn{9}{|c|}{ Long-term streamflow data } \\
\hline $\begin{array}{l}\text { WY 2001-2006 } \\
\text { average of daily } \\
\text { means (August } \\
\text { and September) }\end{array}$ & 5 & $848(a)$ & 32 & 853 (a) & 10 & +5 & +1 & $\begin{array}{l}\text { Estimated tributary inflow (site numbers } 11 \text {, } \\
\text { 14, 20, and 23) equal to September } 2006 \\
\text { measurements. Includes reported withdraw- } \\
\text { als (site numbers } 27,29 \text {, and } 31 \text { ). }\end{array}$ \\
\hline \multicolumn{9}{|c|}{ Summary of 2006 seepage study } \\
\hline 09-06-2006 & 6 & 756 & 10 & 751 & 8 & -5 & -1 & Reach A \\
\hline 09-06-2006 & 10 & 751 & 13 & 693 & 8 & -58 & -8 & Reach B \\
\hline 09-06-2006 & 13 & 714 & 17 & 726 & 5 & +12 & +2 & Reach C \\
\hline 09-06-2006 & 17 & 731 & 22 & 830 & 8 & +99 & +14 & Reach D \\
\hline 09-06-2006 & 22 & 845 & 25 & 741 & 11 & -104 & -12 & Reach E \\
\hline
\end{tabular}




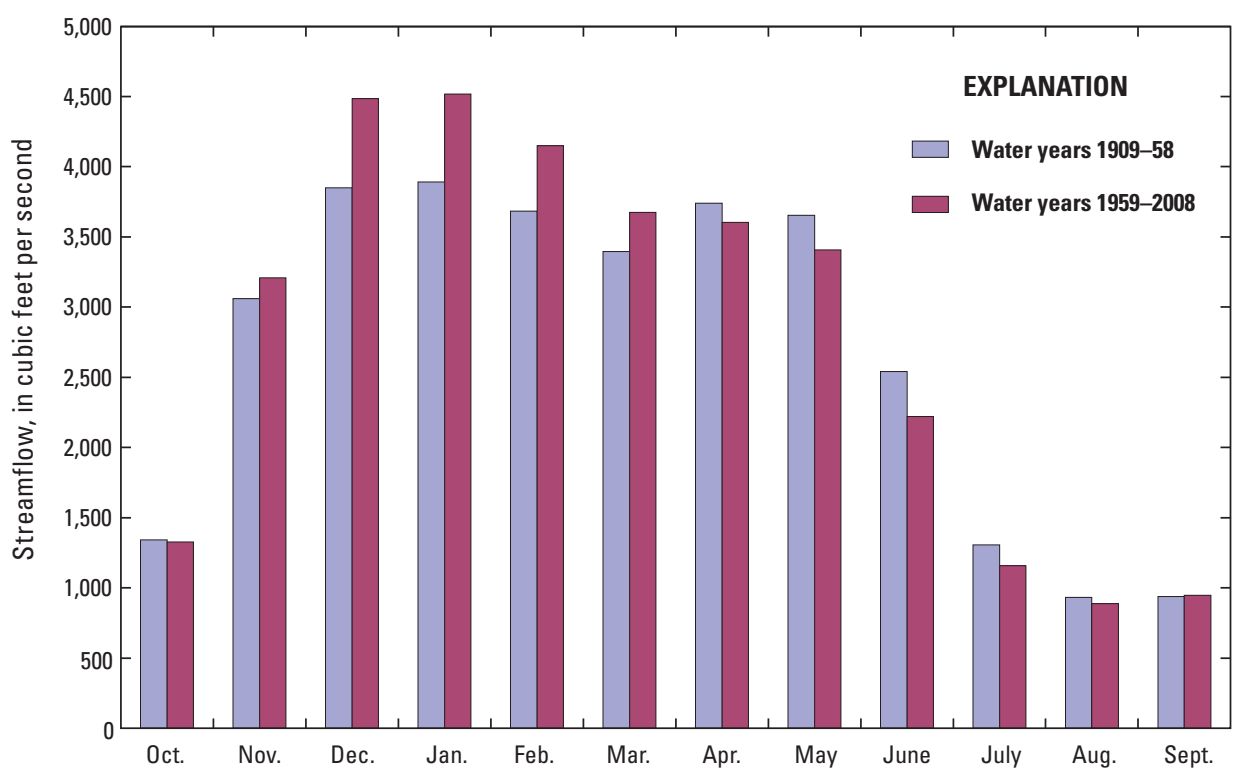

Figure 4. Monthly mean streamflow of the Clackamas River at Estacada, Oregon (site 5).

Tributary inflow was estimated and subtracted from streamflow at the most downstream site. On the basis of streamflow measurements made in September 2006, the combined streamflow of Eagle, Deep, Clear, and Rock Creeks (sites 11, 14, 20, and 23, respectively), was $42 \mathrm{ft}^{3} / \mathrm{s}$, or about 4 percent of the long-term average streamflow at Estacada during August-September.

Daily total municipal withdrawals were added to daily mean streamflow at the Oregon City site (site 32). This step was not necessary for the early period because no municipal withdrawals occur upstream of the Clackamas site (site 25). Withdrawals do occur between the Clackamas and Oregon City sites, so streamflow in the recent period (at the Oregon City site) was adjusted on the basis of hourly withdrawals for three drinking-water treatment plants.

Gains and losses in streamflow from Estacada to either Clackamas (1963-83) or Oregon City (2001-2006) were small and, on average, were less than the uncertainty (table 2). On a year-by-year basis, gains greater than the uncertainty occurred in 6 of the 26 years, and no losses were greater than the uncertainty (fig. 5). The largest gain was $150 \mathrm{ft}^{3} / \mathrm{s}$, or about 14 percent.

Gains in streamflow between sites in the upper basin during late summer are large in comparison to the minimal net gains in the lower $20 \mathrm{mi}$ of the river. The Clackamas River basin lies within three hydrogeologic areas (Conlon and others, 2005). The upper basin, the part of the basin upstream of Estacada, is primarily within the High Cascade and Western Cascade areas (fig. 1). The lower basin is mainly within the Willamette Lowland area. For this analysis, streamflow was normalized for the size of the contributing area between sites by dividing the calculated streamflow between sites by the size of the contributing area. The locations of the streamflow monitoring sites and the associated contributing areas do not exactly coincide with the boundaries of the hydrogeologic areas. As a result, the headwaters of some tributary basins are partly within the adjacent upgradient area. This analysis is based on average August-September streamflow from water years 1963-83 and 2001-06. No adjustments were made for tributary inflow due to lack of data.

Streamflow gains decreased from upstream to downstream. The gain in streamflow associated with the High Cascade area was calculated as the difference in late-summer streamflow between Oak Grove Fork at Government Camp (Timothy Lake) (site 1) and Oak Grove Fork above Power Plant Intake (site 2) (table 3). The gain in streamflow was $3.2\left(\mathrm{ft}^{3} / \mathrm{s}\right) / \mathrm{mi}^{2}$, greater than the uncertainty.

The part of the Clackamas River basin draining the Western Cascade area is represented in two segments, (1) an upper segment from Oak Grove Fork above Power Plant intake (site 2) to Clackamas River above Three Lynx Creek (site 3) and (2) a lower segment from Clackamas River above Three Lynx Creek (site 3) to Clackamas River at Estacada (site 5). Gains were about $1.2\left(\mathrm{ft}^{3} / \mathrm{s}\right) / \mathrm{mi}^{2}$ in the upper segment and $0.8\left(\mathrm{ft}^{3} / \mathrm{s}\right) / \mathrm{mi}^{2}$; both were greater than the uncertainty.

Streamflow gain in the lower Clackamas River basin, which drains part of the Willamette Lowland area, was calculated as the difference in late-summer streamflow between the sites at Estacada (site 5) and sites near the mouth of the Clackamas River (sites 25 and 32 for the 1963-83 and 2001-06 periods, respectively). The increase in streamflow of $0.3\left(\mathrm{ft}^{3} / \mathrm{s}\right) / \mathrm{mi}^{2}$ was less than the uncertainty.

The relatively large gain in streamflow between sites in the upper basin was primarily attributable to the contribution of groundwater, which is a key source of basinwide streamflow during the summer. Groundwater inputs in the lower basin, although smaller than those of the upper basin, may, nonetheless, affect water quality in the lower basin. 


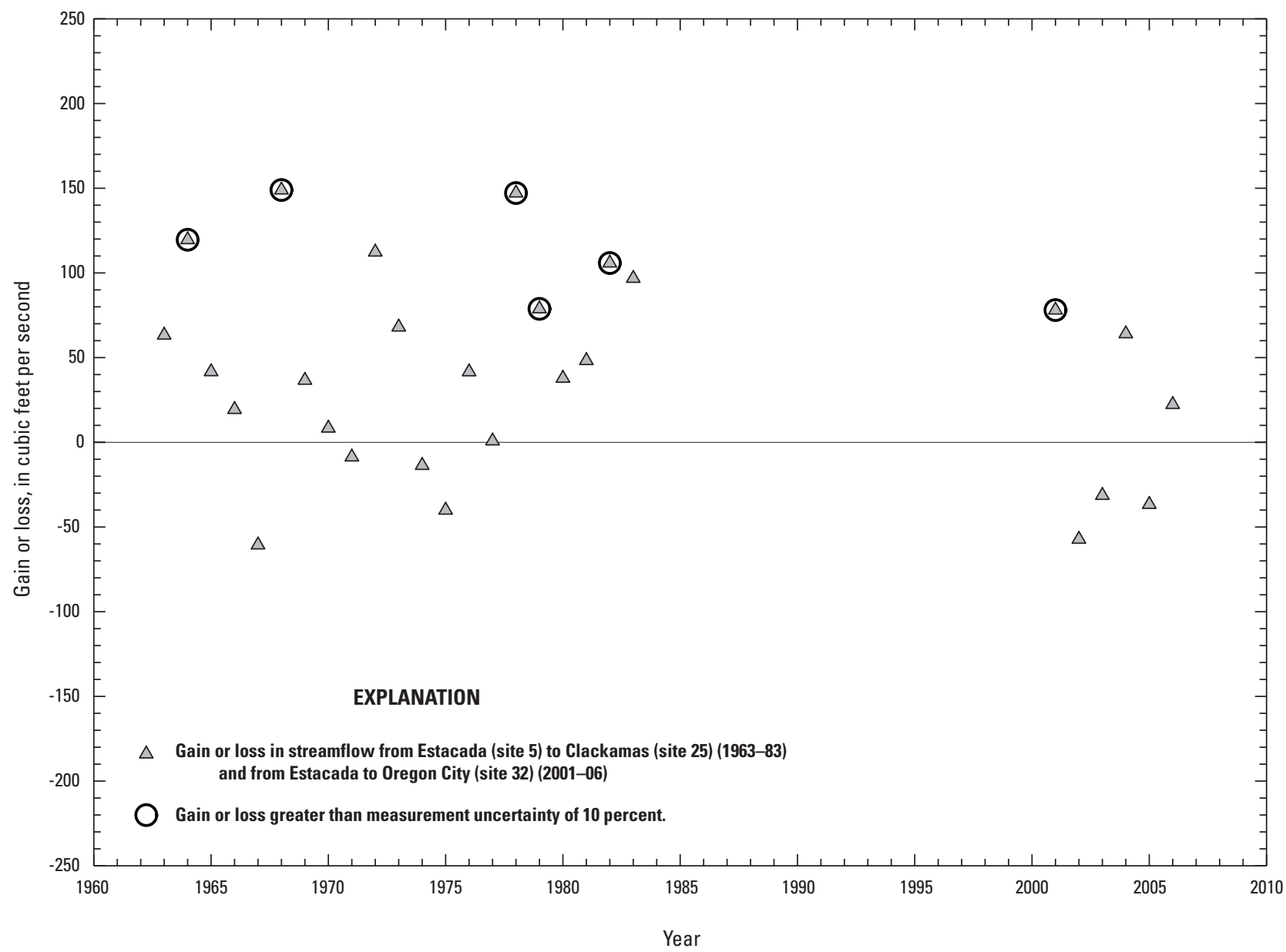

Figure 5. Streamflow gains and losses of the lower Clackamas River, Oregon, based on measurements during AugustSeptember 1963-83 and 2001-06.

Table 3. Streamflow gains of the Clackamas River, Oregon, within three hydrogeologic areas of the Willamette River basin, 1963-83 and 2001-06.

[Upstream and downstream monitoring site number: See table 1; locations of sites are shown in figures 1 and 2. Gain in streamflow: Based on data from August and September 1963-83 and 2001-06. Values in bold are significant (greater than the streamflow uncertainty). A bbreviations: (a), average; $\mathrm{mi}^{2}$, square mile; $\mathrm{ft}^{3} / \mathrm{s}$, cubic foot per second; $\left(\mathrm{ft}^{3} / \mathrm{s}\right) / \mathrm{mi}^{2}$, cubic foot second per square mile]

\begin{tabular}{lcccc}
\hline $\begin{array}{c}\text { Hydrogeologic } \\
\text { area }\end{array}$ & $\begin{array}{c}\text { Upstream and } \\
\text { downstream } \\
\text { monitoring } \\
\text { site number }\end{array}$ & $\begin{array}{c}\text { Intervening } \\
\text { drainage } \\
\text { area } \\
\left(\mathbf{m i}^{2}\right)\end{array}$ & $\begin{array}{c}\text { Gain in streamflow } \\
\text { over intervening } \\
\text { drainage area } \\
\left(\mathbf{f t}^{3} / \mathbf{s}\right)\end{array}$ & $\begin{array}{c}\text { Normalized gain } \\
\text { over intervening } \\
\text { drainage area } \\
\left(\left[\mathbf{f t}^{3} / \mathbf{s}\right] / \mathbf{m i}^{2}\right)\end{array}$ \\
\hline High Cascade & 1,2 & 70 & $\mathbf{2 2 3}$ & $\mathbf{3 . 2}$ \\
Western Cascade (upper) & 2,3 & 355 & $\mathbf{4 4 6}$ & $\mathbf{1 . 2}$ \\
Western Cascade (lower) & 3,5 & 192 & $\mathbf{1 6 0}$ & $\mathbf{0 . 8}$ \\
Willamette Lowland & 5,25 & & 70 & \\
& $(1963-83)$ & $265(\mathrm{a})$ & & \\
& 5,32 & & & \\
& $(2001-06)$ & & & \\
\end{tabular}


Carpenter (2003) identified high nutrient contributions to the lower Clackamas River from shallow wells and seeps. Owing to the relatively high main-stem streamflow and associated uncertainty, the volume of these inputs may be difficult to determine using the methods described in this report.

\section{Seepage Study}

The 2006 seepage study took place over a 2-day period, September 6-7, 2006. Climate conditions were seasonably warm and dry, with only 0.1 in. of precipitation during the previous month at Portland (National Climatic Data Center, 2011). Clackamas River streamflow in August and September is typically the lowest for any two contiguous months of the year (fig. 4). Streamflow at Estacada on September 5, the day prior to most streamflow measurements, ranged from 740 to $810 \mathrm{ft}^{3} / \mathrm{s}$ (fig. 3). Streamflow on September 6 ranged from 755 to $780 \mathrm{ft}^{3} / \mathrm{s}$, or about a 2 percent deviation from the daily mean streamflow of $768 \mathrm{ft}^{3} / \mathrm{s}$. Some measurements were made the following day to confirm the September 6 measurements. Streamflow on September 7 ranged from 766 to $785 \mathrm{ft}^{3} / \mathrm{s}$, except for a rise from a dam release that occurred later in the day after measurements were completed.

The seepage study focused on the lower Clackamas River, between Estacada and Oregon City (fig. 6). Tributaries Eagle, Deep, Foster, Richardson, Clear, Rock, Sieben, Carli, and Cow Creeks were measured. Of the tributaries, only Eagle, Deep, Clear, and Rock Creeks (sites 11, 14, 20, and 23, respectively) were used in seepage calculations because the sum of streamflow for the remainder of the tributary streams was less than 0.1 percent of the streamflow of the Clackamas River. There is one withdrawal from the study reach, at site 27.

The lower Clackamas River was measured at 13 sites on September 6, 2006, followed by measurements at 2 sites the next day (table 4). Many of the site-to-site differences were within the range of uncertainty, indicating that if gains or losses occur, they are small relative to total streamflow. Gains and losses, indicated by site-to-site differences in streamflow that were greater than the uncertainty, occurred at about a quarter of the sites. The maximum gain or loss on a site-to-site basis was 12 percent.

The September 6, 2006, measurements were grouped into reaches on the basis of seepage characteristics and the geomorphic setting. Six reaches were designated: A (beginning near Estacada) through F (terminating near Oregon City) (fig. 2, table 2). Gains or losses greater than the uncertainty occurred in three of the reaches.

Reach A extended from Estacada to just upstream of Eagle Creek (fig. 2). Streamflow measurements in that reach were made at sites $6,7,8,9$, and 10 . The change in streamflow between sites 6 and 10 was less than the uncertainty (table 2).
Reach B extended from just upstream of Eagle Creek to Barton Bridge (fig. 2). Measurements were made at sites 10, 12, and 13, and in Eagle Creek (site 11). The loss from the river at sites $10-13$ was $58 \mathrm{ft}^{3} / \mathrm{s}$ ( 8 percent), equal to the uncertainty, and is considered significant. This loss may be attributable to infiltration through permeable streambed sediments. The stream channel in this area is subject to lateral migration and changed abruptly during the 1996 flood, capturing a near-stream gravel mine and cutting off a former meander created by a long dike used to protect the gravel mine (Wampler, 2004). Die-off of riparian vegetation following the 1996 avulsion suggests a linkage of the shallow aquifer through gravel deposits to the stream. In addition to changes in the active stream channel, this reach, compared to reach A (adjacent upstream) and reach C (adjacent downstream) features a broader, more meandering stream channel configuration (Burkholder, 2007).

Table 4. Streamflow gains and losses in the lower Clackamas River, Oregon, September 6-7, 2006.

[Site number: See table 1; locations of sites are shown in figure 2. Tributaries and withdrawals are depicted in italic. Values greater than streamflow uncertainty are depicted in bold. Gain or loss is from next site upstream. Abbreviations: $\mathrm{ft}^{3} / \mathrm{s}$, cubic foot per second; + , gain from upstream site; - , loss from next site; (a), average of two measurements; (b), from streamflow monitoring site; (c), reported; (d), estimated]

\begin{tabular}{|c|c|c|c|c|c|}
\hline \multirow{2}{*}{$\begin{array}{c}\text { Site } \\
\text { number }\end{array}$} & \multirow{2}{*}{$\begin{array}{c}\text { Date } \\
\text { and time }\end{array}$} & \multirow{2}{*}{$\begin{array}{c}\text { Streamflow } \\
\left(\mathrm{ft}^{3} / \mathrm{s}\right)\end{array}$} & \multirow{2}{*}{$\begin{array}{c}\text { Streamflow } \\
\text { uncertainty } \\
\text { (percent) }\end{array}$} & \multicolumn{2}{|c|}{ Gain or loss } \\
\hline & & & & $\left(\mathrm{ft}^{3} / \mathrm{s}\right)$ & (percent) \\
\hline 6 & $09-06 \quad 0915$ & 756 & 5 & & \\
\hline 7 & $09-06 \quad 0955$ & 747 & 5 & -9 & -1 \\
\hline 8 & $09-06 \quad 1325$ & 752 (a) & 5 & +5 & +1 \\
\hline 9 & 09-06 1330 & 732 & 8 & -20 & -3 \\
\hline 10 & $09-06 \quad 1450$ & 751 & 8 & +19 & +3 \\
\hline 11 & $09-06 \quad 1000$ & $21.0(a)$ & 8 & & \\
\hline 12 & $09-06 \quad 1755$ & 753 & 5 & -19 & -3 \\
\hline 13 & $09-06 \quad 1325$ & 714 & 5 & -39 & -5 \\
\hline 14 & $09-06 \quad 1215$ & $5.1(\mathrm{a})$ & 8 & & \\
\hline 15 & $09-06 \quad 1655$ & 726 & 5 & +7 & +1 \\
\hline 17 & 09-06 1910 & 731 & 5 & +5 & +1 \\
\hline 19 & $09-06 \quad 1255$ & 793 & 5 & +62 & 8 \\
\hline 20 & $09-06 \quad 1600$ & 14.9 (a) & 5 & & \\
\hline 22 & 09-06 1100 & 845 & 8 & +37 & +5 \\
\hline 23 & $09-06 \quad 0740$ & $1.3(\mathrm{a})$ & 11 & & \\
\hline 25 & $09-06 \quad 0840$ & 742 & 11 & -104 & -12 \\
\hline 27 & 09-06 1000 & -16 (c) & 5 & & \\
\hline 28 & $09-06 \quad 1230$ & 766 (a) & 5 & +40 & +5 \\
\hline 5 & 09-07 0600 & 779 (b) & 10 & & \\
\hline $\begin{array}{l}11,14, \\
20,23\end{array}$ & 09-07 & $42(d)$ & 8 & & \\
\hline 25 & $09-07 \quad 1245$ & 772 & 8 & -49 & -6 \\
\hline 27 & 09-07 1300 & $-17(c)$ & 5 & & \\
\hline 28 & 09-07 1427 & 800 & 11 & 45 & +6 \\
\hline
\end{tabular}




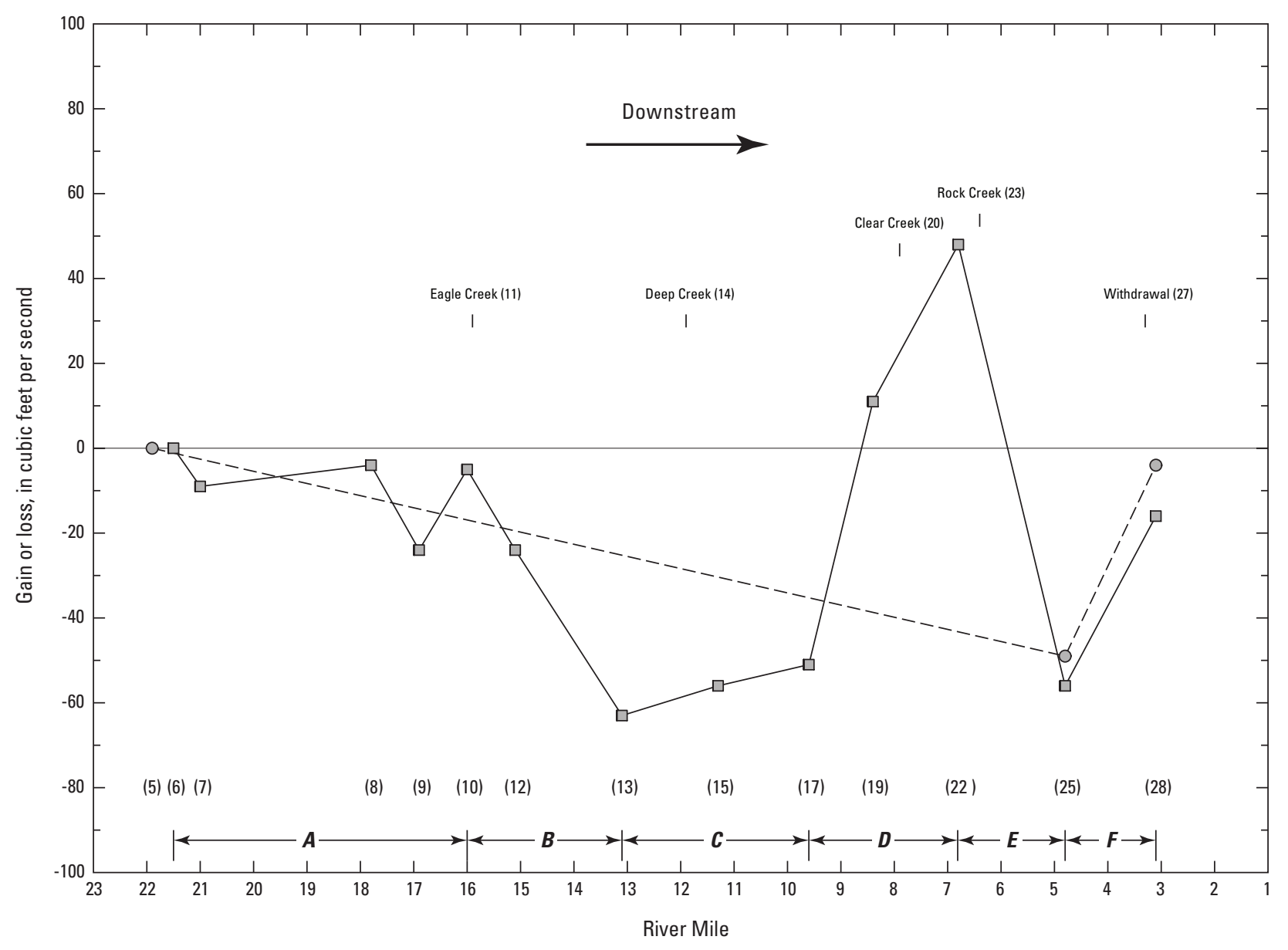

\section{EXPLANATION}

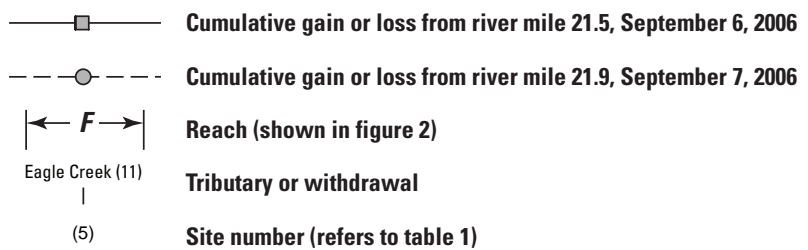

Figure 6. Streamflow gains and losses of the lower Clackamas River, Oregon, September 2006. 
Reach C is near Barton. Main-stem measurements were made at sites 13, 15, and 17, and in Deep Creek (site 14). The change in streamflow between sites 13 and 17 was less than the uncertainty.

Reach D extends from near Barton to near Carver, just upstream of Rock Creek. Measurements were made at sites 17, 19, and 22. Clear Creek (site 20), which enters in this reach, was also measured. The gain between sites 17 and 22 was $99 \mathrm{ft}^{3} / \mathrm{s}$ (14 percent), greater than the uncertainty. Streamflow at the downstream end of this reach was the greatest for any site measured on September 6. The gain in reach D may be attributable to the basin-scale constriction in the landscape at Carver, where the Clackamas River passes through a notch between hills to the southwest and northeast, and subsurface flow may be directed back to the active stream channel.

Reach $\mathrm{E}$ is from near Carver to near Clackamas. Measurements were made at sites 22 and 25. Rock Creek (site 23) enters in this reach and was measured. The loss of $104 \mathrm{ft}^{3} / \mathrm{s}$ (12 percent) was greater than the uncertainty. The loss could be attributable to recharge through the streambed to alluvial and Pleistocene Clackamas River terrace deposits. The terrace deposits may occupy part of an abandoned (pre-catastrophic flood) stream channel extending westward from the northernmost extent of the Clackamas River at about river mile 6.0 (Madin, 1990).

Reach F, the most downstream reach, extends from near Clackamas to near Oregon City. Main-stem measurements were made at sites 25 and 28 . There is one withdrawal in this reach. The change in streamflow between sites 25 and 28 was less than the uncertainty.

Streamflow measurements were made the following day (September 7, 2006) at sites 25 and 28. These measurements, coupled with continuous streamflow data from the Estacada site (5); estimated tributary inflow based on measurements from the previous day; and municipal withdrawal, confirmed the results at these sites from the previous day (fig. 6). The net change in streamflow between sites 5 and 25 (incorporating reaches A through E), and between sites 25 and 28 (reach F) were less than the uncertainty. As a whole, the net change in streamflow of the Clackamas River from Estacada to near Oregon City (reaches A through F) on September 6 and 7 was less than the uncertainty.

\section{Suggestions for Further Study}

Additional information is needed to quantify small gains and losses relative to streamflow. In particular, more information is needed to identify the uncertainty of streamflow measurements and understand the relation of near-stream groundwater level to stream level.
Multiple streamflow measurements at a given location, as well as measurements a short distance upstream and downstream, could justify a narrowing of the uncertainty ratings typically assigned to streamflow measurements. For example, corroboration of streamflow at a given location from one hour to the next, as well as from one location to locations 1-2 channel widths upstream and downstream, could provide insight into the "true" streamflow. This could be accomplished by streamflow measurements at a subset of sites selected from the 2006 study. For this approach, measurements could be made at the Estacada, Barton, Carver, Clackamas, and Oregon City sites $(6,13,22,25$, and 28 , respectively).

High nutrient concentrations observed in near-stream wells and springs (Carpenter, 2003) suggest that the Clackamas River might be receiving nutrients from groundwater discharge by way of springs and/or seepage. Little is known, however, about the seasonal fluctuation of groundwater levels near the river and the relation of these water levels to stream level. A network of groundwater observation wells coupled with periodic stream-level measurements could provide an indication of the timing and spatial distribution of the groundwater contribution to the lower Clackamas River, which could facilitate an assessment of nutrient loading to the stream.

\section{Summary}

Quantification of seepage characteristics of the lower 20 river miles of the Clackamas River, from Estacada to Oregon City, Oregon, was derived from individual streamflow measurements and decades of streamflow data. Interpretation of gains and losses in streamflow based on historical measurements was aided by analysis of time-of-travel of water pulses released from River Mill Dam. Many site-to-site differences in streamflow were relatively small.

Gains and losses of streamflow of the lower Clackamas River, after accounting for tributary inflows and withdrawals, are discernible on mile-by-mile and reach scales, and can be attributed to the geomorphic setting of the basin. The loss in streamflow between Estacada and Barton, confirmed by measurements in May 1992 and September 2006, is attributable to infiltration into recently reworked streambed sediments. The streamflow gain between Barton and Carver was confirmed by measurements in September 1998 and September 2006. The gain is attributable to a basin-scale constriction in the stream channel that forces subsurface flow to the active stream channel through shallow stream deposits overlying relatively impermeable sandstone. Downstream of Carver, the stream intersects permeable Pleistocene flood deposits and loses streamflow between Carver and Clackamas, based on streamflow measurements made in September 2006. 
Many gains and losses in the Clackamas River from Estacada to Clackamas and Oregon City are less than the uncertainty, indicating that if gains or losses actually are occurring, they are small relative to the total streamflow. On the basis of August-September daily mean streamflow, and after accounting for tributary inflows and withdrawals, only in some years were gains from Estacada to sites at Clackamas and Oregon City greater than the uncertainty, and no losses exceeded the uncertainty. Generally, these results were confirmed by streamflow measurements made in August 1987 and September 2006.

Gains in streamflow in the lower Clackamas River during summer are smaller than gains in the upper basin. On a per-unit-area basis, gains in streamflow were greatest in the High Cascades geomorphic area, diminished in the Western Cascades area, and less than the uncertainty in the part of the Clackamas River draining the Willamette Lowland area, downstream from Estacada.

\section{Acknowledgments}

The author thanks Kim Swan (Clackamas Watershed Management Group) and Chris Berger (Portland State University) for drinking-water treatment plant withdrawal data. Staff from USGS field offices in Central Point and Portland made the numerous streamflow measurements in 2006. Kurt Carpenter (USGS Portland) selected the 2006 measurement sites, coordinated field crews, and provided insight from a decade of study of the Clackamas River.

\section{References Cited}

Alexander, C.W., Herrett, T.A., Kraus, R.L., Moffatt, R.L, and Smith, M.L., 1987, Water resources data Oregon, water year 1987: U.S. Geological Survey Water-Data Report OR-87-2, $386 \mathrm{p}$.

Burkholder, B.K., 2007, Influence of hyporheic flow and geomorphology on temperature of a large, gravel-bed river, Clackamas River, Oregon, USA: Corvallis, Oregon State University, Master's thesis, 192 p., accessed May 7, 2010, at http://ir.library.oregonstate.edu/jspui/bitstream/1957/7607/1/ Burkholder_thesis.pdf.
Carpenter, K.D., 2003, Water-quality and algal conditions in the Clackamas River basin, Oregon, and their relations to land and water management: U.S. Geological Survey WaterResources Investigations Report 02-4189, 114 p. (Also available at http://pubs.usgs.gov/wri/WRI02-4189/.)

Clackamas River Water Providers, 2011, Our source-Clackamas River watershed: Clackamas River Water Providers website, accessed February 2, 2011, at http://www.clackamasproviders.org/water-resources/our-source.html.

Conlon, T.D., Wozniak, K.C., Woodcock, Douglas, Herrera, N.B., Fisher, B.J., Morgan, D.S., Lee, K.K., and Hinkle, S.R., 2005, Ground-water hydrology of the Willamette basin, Oregon: U.S. Geological Survey Scientific Investigations Report 2005-5168, 83 p., 1 pl. (Also available at http://pubs.er.usgs.gov/pubs/sir/sir20055168.)

Herrett, T.A., Hess, G.W., House, J.G., Ruppert, G.P., and Courts, M.L., 2001, Water resources data Oregon, water year 2001: U.S. Geological Survey Water-Data Report OR-01-1, $430 \mathrm{p}$.

Lee, K.K., 1995, Stream velocity and dispersion characteristics determined by dye-tracer studies on selected stream reaches in the Willamette River basin, Oregon: U.S. Geological Survey Water-Resources Investigations Report 95-4078, 39 p. (Also available at http://pubs.er.usgs.gov/ usgspubs/wri/wri954078.)

Lee, K.K., and Risley, J.C., 2002, Estimates of ground-water recharge, base flow, and stream reach gains and losses in the Willamette River Basin, Oregon: U.S. Geological Survey Water-Resources Investigations Report 01-4215, 52 p. (Also available at http://pubs.er.usgs.gov/usgspubs/wri/ wri014215.)

Madin, I.P., 1990, Earthquake-hazard geology maps of the Portland metropolitan area, Oregon: State of Oregon Department of Geology and Mineral Industries Open-File Report 0-90-2, scale 1:24,000, 21 p., 8 pls.

Madin, I.P., 1994, Geologic map of the Damascus quadrangle, Clackamas and Multnomah Counties, Oregon: Oregon Department of Geology and Mineral Industries, Geological Map Series 60, scale 1:24,000, accessed March 16, 2009, at http://www.oregongeology.org/pubs/GMS/gms060.pdf. 
National Climatic Data Center, 2011, Portland International Airport, Oregon: accessed September 14, 2011, at http:// www4.ncdc.noaa.gov/cgi-win/wwcgi.dll?wwDI $\sim \operatorname{StnSrch~} \sim \mathrm{S}$ tnID 20016428.

Oberg, K.A., Morlock, S.E., and Caldwell, W.S., 2005, Quality assurance plan for discharge measurements using acoustic Doppler current profilers: U.S. Geological Survey Scientific Investigations Report 2005-5183, 35 p. (Also available at http://pubs.er.usgs.gov/usgspubs/sir/sir20055183.)

Oregon State University, 2008, Oregon Imagery ExplorerNatural Resources Digital Library, 2005 half-meter orthoimagery: accessed March 18, 2009, at http://oregonexplorer. info/imagery/about/about.aspx?Res=17218.

Piper, A.M., 1942, Ground-water resources of the Willamette Valley, Oregon: U.S. Geological Survey Water-Supply Paper 890, $194 \mathrm{p}$.
PRISM Group, 2008, Precipitation (Normals): Corvallis, Oregon State University database, accessed April 28, 2010, at http://prism.oregonstate.edu/products/viewer.phtml?file=/ pub/prism/us_30s/grids/ppt/Normals/us_ppt_1971_2000.14. gz\&year $=1971 \quad 2000 \&$ vartype $=p p t \&$ month $=14 \&$ status $=$ fi nal.

Rantz, S.E., and others, 1982, Measurement and computation of streamflow: U.S. Geological Survey Water Supply Paper 2175, 2 v., 631 p. (Also available at http://pubs.usgs.gov/ wsp/wsp2175/.)

Wampler, P., 2004, Contrasting geomorphic responses to climatic, anthropogenic, and fluvial change across modern to millennial time scales, Clackamas River, Oregon: Corvallis, Oregon State University, Ph.D. thesis, 173 p., accessed March 16, 2009, at http://ir.library.oregonstate.edu/dspace/ handle/1957/10071. 
Seepage Investigations of the Clackamas River, Oregon

This page left intentionally blank. 
Publishing support provided by the U.S. Geological Survey

Publishing Network, Tacoma Publishing Service Center

For more information concerning the research in this report, contact the Director, Oregon Water Science Center

U.S. Geological Survey

2130 SW 5th Avenue

Portland, Oregon 97201

http://or.water.usgs.gov 
